\title{
An initial framework for the role of leader fear in the knowing-doing gap of leadership
}

Book or Report Section

Accepted Version

Ahmadi, A., Vogel, B. and Collins, C. (2016) An initial framework for the role of leader fear in the knowing-doing gap of leadership. In: Ashkanasy, N. M., Zerbe, W. J. and Härtel, C. E. J. (eds.) Emotions and Organizational Governance. Research on Emotion in Organizations, 12. Emerald Group Publishing Limited, Bingley, pp. 313-340. ISBN 9781785609985 doi: https://doi.org/10.1108/S1746979120160000012011 Available at https://centaur.reading.ac.uk/66762/

It is advisable to refer to the publisher's version if you intend to cite from the work. See Guidance on citing.

Published version at: http://dx.doi.org/10.1108/S1746-979120160000012011

To link to this article DOI: http://dx.doi.org/10.1108/S1746-979120160000012011

Publisher: Emerald Group Publishing Limited

All outputs in CentAUR are protected by Intellectual Property Rights law, including copyright law. Copyright and IPR is retained by the creators or other copyright holders. Terms and conditions for use of this material are defined in the End User Agreement. 


\section{www.reading.ac.uk/centaur}

\section{CentAUR}

Central Archive at the University of Reading

Reading's research outputs online 


\author{
DR AMAL AHMADI \\ Henley Business School \\ University of Reading \\ Whiteknights \\ Reading, Berkshire \\ RG6 6UR \\ United Kingdom \\ Phone: +44(0)7592134961 \\ Email: a.a.ahmadi@reading.ac.uk
}

\title{
DR BERND VOGEL
}

Henley Business School

University of Reading

Greenlands

Henley-on-Thames, Oxfordshire

RG9 3AU

United Kingdom

Phone: $+44(0) 1491414548$

Email: bernd.vogel@henley.ac.uk

\section{DR CLAIRE COLLINS}

Henley Business School

University of Reading

Greenlands

Henley-on-Thames, Oxfordshire

RG9 3AU

United Kingdom

Phone: +44(0)1491414545

Email: claire.collins@henley.ac.uk 


\title{
Running head
}

Initial Framework on Fear and the Leadership Knowing-Doing Gap

\begin{abstract}
Purpose: We take an affect-based approach to theoretically introduce and explore the knowing-doing gap of leadership. We focus on the emotion of fear that managers may experience in the workplace, and how it may influence the transfer of their leadership knowledge into leadership action.

Approach: We use Affective Events Theory as our underlying theoretical lens, drawing on emotional, cognitive and behavioral mechanisms to explain the role of fear in the widening and bridging of the knowing-doing gap of leadership.

Findings: We theoretically explore the interplay between leader fear, the leadership contexts and the knowing-doing gap of leadership. From this, we develop a multidimensional theoretical framework that provides a starting point for understanding fear and the knowing-doing gap of leadership.

We highlight how fear and the knowing-doing gap of leadership may be influenced by and potentially impact on individual managers and their leadership contexts.

Originality/value: Our initial theoretical framework provides a starting point for understanding fear and the knowing-doing gap of leadership. It has implications for future research to enhance our understanding of the topic, and contributes towards existing approaches on leadership development as well as emotions and leadership.
\end{abstract}

\section{Keywords}

Leadership; Leadership development; Affective Events Theory; Emotion; Fear 
Interest in leadership development theory, research and practice has grown considerably over the past three decades (Collins \& Holton, 2004; Day, 2000; Day, 2011; Day, Fleenor, Atwater, Sturm, \& McKee, 2014). However, understanding leadership development and building knowledge about leadership more often than not remains an end in itself in practice, with relatively little attention paid to the transfer of leadership learning into actual leadership practice (Weber, 2011) and the return on development investment (Avolio, Avey, \& Quisenberry, 2010). Managers learn leadership from experiences on the job (McCall, 2004; Rubin \& Dierdorff, 2009; Tannenbaum, 1997), enact leadership as a form of tacit knowledge (Hedlund, Forsythe, Horvath, Williams, Snook, \& Sternberg, 2003), or acquire leadership knowledge through leadership development programs and practices (Hannah \& Avolio, 2010; Kark, 2011), such as 360-degree feedback, coaching, mentoring, networking and action learning (Day, 2000). However, they may not necessarily transfer the leadership learning that they accumulate from the various forms of leadership knowledge acquisition into real leadership action on the job.

Scholars have begun to explore the transfer of management learning and education into practice in organizations. Recent work suggests that what managers learn is not always fully utilized or turned into action in real contexts (Bennis \& O'Toole, 2005; Hoover, Giambatista, Sorenson, \& Bommer, 2010). Research shows that knowing (conceptual and procedural knowledge) does not necessarily predict doing (applied knowledge) (Baldwin, Pierce, Joines, \& Farouk, 2011). Additionally, those who possess strong cognitive knowledge may have not developed the behavioral skills and emotional commitment required for actions on the job (Hoover et al., 2010). Hence, it is often unknown to what extent managers develop and then perform differently back on the job (Blume, Ford, Baldwin, \& Huang, 2010). Pfeffer 
and Sutton (2000) address a challenge in management that they refer to as the knowing-doing gap, illustrating how managers fail to translate their knowledge about management practices to enhance organizational performance into action.

This paper looks at the knowing-doing gap specifically from a leadership perspective, focusing on managers' transfer of their leadership knowledge into leadership practice. Given that people spend considerably more time acquiring leadership knowledge than actually applying it (Blanchard, Meyer, \& Ruhe, 2007) an exploration of the knowing-doing gap of leadership is needed. Previous leadership research often neglects the link between leadership development and leadership emergence or leadership performance (Chan \& Drasgow, 2001). Further, the general lack of enquiry on the knowing-doing of leadership may be partly due to the traditional misconception that holding a formal leader role or position within an organizational hierarchy prescribes or inherently conveys leadership (DeRue \& Ashford, 2010). Research as much as practice may take for granted that managers are willing and able to translate what they know about leadership into real leadership action. Thus, the knowing-doing gap of leadership appears to be largely ignored in the leadership literature.

To address this gap, this paper aims for an initial conceptual introduction of managers' knowing-doing gap in leadership, exploring how managers may transfer, to varying degrees in different situations, their leadership knowledge into leadership practice, thereby widening and bridging their leadership knowing-doing gaps at different points in time. Thus, we focus on an initial theoretical exploration of the leadership knowing-doing gap, its conditions and dynamics to ensure that managers not only accumulate knowledge on how to lead, but also implement their leadership learning into actual leadership practice. 
Turning knowledge into real action in organizations may be constrained by emotions, and specifically the emotion of fear. Examples of fear in the workplace include the fear of making errors, the fear of blame, and the fear of job loss, all of which can prevent managers from acting on their knowledge (Pfeffer \& Sutton, 2000). While the workplace was traditionally treated as rational and emotionally neutral, emotions are now viewed as playing a key role in experiences at work in general (Ashkanasy, Zerbe, \& Härtel, 2002, 2005; Brief \& Weiss, 2002; Fineman, 2003; Fisher \& Ashkanasy, 2000; Grandey, 2008) and in leadership in particular (Gooty, Connelly, Griffith, \& Gupta, 2010; Rajah, Song, \& Arvey, 2011). Despite its importance in shaping human behavior in the workplace, fear receives little attention in the organizational emotions literature (Kish-Gephart, Detert, Treviño, \& Edmondson, 2009) and appears to be understudied within the leadership domain. Thus, we take an affect-based approach to conceptualize the leadership knowingdoing gap, with a focus on the emotion of fear that leaders may experience at work.

To this end, we employ Affective Events Theory (Weiss \& Cropanzano, 1996) as our underlying theoretical lens. We further draw on cognitive appraisal theories (Lazarus, 1982; Ortony, Clore, \& Collins, 1990; Roseman \& Smith, 2001; Scherer, 1988; Smith \& Ellsworth, 1985), avoidance and approach behavior responses to fear (Frijda, 1986; Frijda, Kuipers, \& ter Schure, 1989; Ohman \& Wiens, 2003; Rachman, 1990), and contextual theories of leadership (Antonakis, Avolio, \& Sivasubramaniam, 2003; Osborn, Hunt, \& Jauch, 2002; Porter \& McLaughlin, 2006; Shamir \& Howell, 1999) to explain how work events may shape experiences of fear in leaders, which in turn may influence the translation of their leadership learning into leadership practice. From this, we develop a multidimensional theoretical framework that we hope offers a starting point towards an integrative theory of the leadership knowing-doing gap. 
Our initial theoretical framework contributes to existing approaches to leadership development as well as emotions and leadership in at least three ways. First, our framework is one of the first scholarly attempts to uncover the gap between knowing leadership and enacting leadership. We emphasize that the accumulation of leadership knowledge does not necessarily prescribe actual leadership engagement in organizations (Blanchard et al., 2007; Pfeffer \& Sutton, 1999). Thus, we complement existing approaches that challenge the view that holding a formal leadership position in an organization inherently conveys leadership (DeRue \& Ashford, 2010). Second, we add to the scarce literature on negative discrete emotions in the workplace, and the limited existing literature that links fear with leadership. Our theory is one of few scholarly explorations of fear in leaders as opposed to fear of leaders (e.g., Fry, 2003; Ryan \& Oestreich, 1998) within the leadership arena. We contribute specifically by looking at fear in leaders and how it may influence leadership engagement and leadership effectiveness in organizations. Third, we offer an initial theoretical framework in which both fear and leadership are multidimensional, dynamic, and context-specific (Gooty, Gavin, \& Ashkanasy, 2009; Hernandez, Eberly, Avolio, \& Johnson, 2011; Yammarino \& Dansereau, 2008; Yammarino, Dionne, Uk Chun, \& Dansereau, 2005). By drawing on emotional, cognitive and behavioral approaches and integrating them with arguments from individual and contextual leadership theories, we show how fear appraisals, responses and impacts on the leadership knowing-doing gap can vary for each person, between persons, and in different situations. Thus, we contribute towards a more nuanced understanding of both emotions and leadership.

This paper presents our initial understanding the knowing-doing gap within the leadership context with a set of propositions. To this end, we set the scene on the leadership arena and the knowing-doing gap of leadership. We then elaborate on the 
significance of emotions in leadership and explore the role of fear in widening and bridging of the knowing-doing gap of leaders. Next, we discuss the anticipated contributions from our proposed theoretical framework and conclude with suggestions for future research directions.

\section{THEORETICAL BACKGROUND}

\section{Leadership and the Knowing-Doing Gap of Leadership}

The extant leadership literature has been categorized in various ways (e.g., Dansereau, Seitz, Chiu, Shaughnessy, \& Yammarino, 2013; Gardner, Lowe, Moss, Mahoney, \& Cogliser, 2010; Hernandez et al., 2011; Yukl, 2010). A starting point that forms the basis of our perspective on leadership is put forward by Hernandez et al. (2011: 1166-1167); placing leadership theories across two dimensions: (a) the loci of leadership: where leadership comes from, classified as leader, followers, dyads, collectives and contexts; and (b) the mechanisms of leadership: how leadership is transmitted, categorized as traits, behaviors, cognition and affect. We take into account the complexity of leadership, recognizing the co-existence of leaders, followers, dyads, collectives and contexts (Avolio \& Gardner, 2005; Hernandez et al., 2011; Yukl, 2010) and acknowledge the leader-centric views of leader development, as much as the relational and collective approaches to leadership development (Day, 2000; Day, 2011; Day et al., 2014). This pluralistic standpoint on leadership informs our theorizing, yet the vantage point for discussing the knowing-doing gap of leaders is the individual managers in their leadership contexts, and the phenomenon of transferring their individual leadership learning into leadership action. Thus, for the purpose of this paper, we focus on the leader and the context as the main loci of 
leadership. As for the mechanisms of leadership, our underlying theoretical lens of Affective Events Theory focuses primarily on affect, while we draw on the cognition and behaviors mechanisms to support our understanding of the leadership knowingdoing gap.

The knowing-doing gap has been referred to in the training literature as the transfer problem, whereby the acquisition of knowledge and skills through a training experience is not transferred back to the workplace (Baldwin \& Ford, 1988). Applied to leadership, the transfer problem occurs when leadership learning is not translated into actual leadership behavior on the job (Blume et al., 2010). Organizations spend considerable resources to develop their leaders through leadership development interventions, yet there is a lack of follow-up to determine the return on development investment and the desired positive impacts on the attitudes, behaviors and performance of leaders (Avolio et al., 2010). Although leaders often report being enlightened though leadership development and training, they implement few changes in their organizations (Blume et al., 2010; Pfeffer \& Sutton, 2000). People generally spend significantly more time acquiring new leadership knowledge through books, audios, videos and seminars, than actually putting their know-how into action in practice (Blanchard et al., 2007). Thus, while extensive leadership research, education, training and stimulation of leadership learning on the job may contribute towards increased leadership knowing, it may not necessarily yield the desired leadership doing and practice in organizations.

In our understanding of the leadership knowing-doing gap, we look at the gap between knowing leadership on the one hand, for instance through leadership development programs, experience on the job, or other forms of leadership learning and knowledge acquisition, and doing leadership on the other hand, in the form of 
enacting leadership behavior and engaging in leadership in the workplace. We draw on relevant concepts such as knowledge-in-use (de Jong \& Ferguson-Hessler, 1996), applied management knowledge (Baldwin et al., 2011), and the motivation to lead (Chan \& Drasgow, 2001), as well as previous work on the psychology of doing nothing and people's preference for non-action (Anderson, 2003; Steel, 2007). Thus, we define the leadership knowing-doing gap as a state in which managers cognitively know what leadership entails, as well as how to engage in leadership and in what situations, yet do not fully translate their leadership knowing into real leadership behavior, and thereby do not engage in leadership doing.

We view the translation of leadership knowledge into leadership action as a context-specific and dynamic process. Within the training literature, the transfer of learning into practice consists of two dimensions: (a) generalization: the degree to which learning is applied to different contexts and situations; and (b) maintenance: the extent to which the resulting changes from learning continue over time (Blume et al., 2010: 1067-1068). We build on this perspective of transfer in describing the knowing-doing gap of leadership, drawing on literature that highlights the influence of work environments and organizational climates on the transfer of learning into practice (Avolio et al., 2010; Blume et al., 2010; Rogg, Schmidt, Shull, \& Schmitt, 2001), as well as contextual theories of leadership that emphasize the significance of context characteristics in influencing leadership behavior and effectiveness (Antonakis et al., 2003; Osborn et al., 2002; Porter \& McLaughlin, 2006; Shamir \& Howell, 1999). We further draw on event-based literature that points to the impact of different kinds of events in shaping the cognitions, affects, attitudes, behaviors and performance of individuals in organizations (Gersick \& Hackman, 1990; Lee \& Mitchell, 1994; Louis, 1980; Monson, Hesley, \& Chernick, 1982; Morgeson, 2005; 
Morgeson \& DeRue, 2006; Trevino, 1992; Weiss \& Cropanzano, 1996). From this, we view the leadership knowing-doing gap as a state that has an inherent dynamic and changes over time across various contexts and events. For instance, in a particular situation, a manager might have a wide gap between what they know about leadership and what they actually do in terms of leadership engagement at work. In another situation, they might tap further into their leadership knowledge and more actively transfer that into real leadership action, thereby preventing or bridging their leadership knowing-doing gap. Thus, at a point in time, a manager's current leadership knowing-doing gap reflects the extent to which there is a gap present in their translation of their leadership knowing into leadership doing. It follows from this that the state of the knowing-doing gap varies amongst different leaders, and the extent of the knowing-doing gap for an individual leader is also dynamic, stretching and closing in different situations, or in similar situations at different points in times.

Proposition 1: The extent of the leadership knowing-doing is shaped by the interplay between the individual leaders and their situational contexts.

\section{Emotions and Leadership}

A large and growing body of literature has investigated affects (emotions and moods) as important performance predictors in organizations (Brief \& Weiss, 2002; Fisher, 2000; Weiss, Nicholas, \& Daus, 1999a; Wright, Bonett, \& Sweeney, 1993; Wright \& Cropanzano, 1998). Theory and research on affect in the workplace differentiates between emotions and moods. Emotions refer to short-lived feelings that have a cognitive content associated with a specific cause, an object, a person, or an event, like being afraid of snakes or angry with a boss, for example. Moods, on the 
other hand, are feeling states that last longer, they do not come and go like emotions, and are not necessarily context-specific nor attached to any particular occurrence or object (Ashkanasy et al., 2002; Fineman, 2003; Forgas, 1995; Gooty et al., 2010; Izard, 1993; Thayer, 1989). While there are various definitions of emotions and moods in the affect literature (Gooty et al., 2009), a key difference between the two is that emotions can be sufficiently intense to disrupt ongoing human functioning such as thought processes and behaviors (Brief \& Weiss, 2002; Ostell, 1996) whereas moods are generally not intense enough to have such an impact (Rajah et al., 2011). For instance, evidence shows that emotions play an important role in judgment and decision-making (Forgas, 1995; Huy, 2012; Lerner \& Keltner, 2000). Our theory illustrates how emotions may influence leadership, looking specifically at leader fear and its impact on the leadership knowing-doing gap.

Within the leadership domain, the significance of emotionality lies for instance in its impact on leadership behavior, relationships with followers, decisionmaking, and performance (Rajah et al., 2011). One of the prevailing themes in the leadership and affect literature is discrete emotions and leadership (Gooty et al., 2010; Rajah et al., 2011). Within this arena, negative leader emotions appear to be understudied compared to positive leader emotions (Gooty et al., 2010). There has been a fascination with positive emotions in the organizational literature in general, with a comparably limited understanding of negative employee feelings at work (Maitlis \& Ozcelik, 2004). The negative discrete emotion of fear appears to be underexplored within scholarly leadership theory and research as compared with practitioner publications. We explore how it may influence the translation of managers' knowledge of leadership into real leadership engagement in the workplace. 
To conceptually explore the role of fear in the knowing-doing of leadership, we draw on Affective Events Theory, which offers a "macrostructure" to understand emotions at work (Weiss \& Beal, 2005: 2). Affective Events Theory states that organizational characteristics and conditions and every day work events (hassles and uplifts) are affective events in that they can initiate or influence the emotions of members, which in turn can have an impact on their behaviors, attitudes and performance (Weiss \& Cropanzano, 1996). Affective Events Theory has received various theory and research applications within the leadership arena. Examples include its use as a framework for understanding charismatic leadership behavior emergence (Walter \& Bruch, 2009); transformational leadership climate (Menges, Walter, Vogel, \& Bruch, 2011), the impact of leader affect on follower attitudes and performance using failure feedback situations as affective events (Gaddis, Connelly, \& Mumford, 2004), as well as looking at leaders as sources of affective events and exploring follower emotional responses to leader behaviors (Dasborough, 2006). As the workplace can trigger negative emotions such as fear (Maitlis \& Ozcelik, 2004) and due to its potential to influence the transfer of knowing into doing (Pfeffer \& Sutton, 2000), our proposed theoretical framework looks at how managers may experience fear, and how their fear experiences can disrupt or promote the translation of their leadership learning into leadership action, as depicted in Figure 1 and expanded on below.

[Take in Figure 1 here] 
Fear can be defined as the experience of being "afraid or apprehensive" resulting from an "anticipation or awareness of danger" (Merriam-Webster Dictionary, 2012). It is classified as a negative emotion that describes unpleasant feelings (Maitlis \& Ozcelik, 2004), and a discrete emotion that is triggered by a specific cause or target (Barsade \& Gibson, 2007), alongside other emotions that result from threats, harms and losses, like anger, guilt and sadness (Lazarus, 1991b).

While there is some research exploring leadership as a source of fear for employees, i.e. employees experiencing fear of leaders (Fry, 2003; Ryan \& Oestreich, 1998), there seems to be minimal work to date looking at fear in leaders, i.e. managers experiencing fear themselves. The generalizability of much published work on fear in leaders is problematic, as it is largely dominated by practitioner publications, with limited scholarly investigation of the topic. Examples of leader fear discussed in practitioner publications include the fear of making mistakes, fear of failure, fear of appearing weak, and the fear of mockery (Carter, 2009). Some examples relate to how the leadership role may inherently raise fears such as the fear of blame in being responsible for how other people perform, as well as the fear of displeasing people (Weiss, 2004). On the other hand, the contexts in which leaders operate may similarly pose various threats, leading for example to the fear of the unknown or the fear of change (Colonna, 2006).

\section{Development of Leader Fear}

Affective Events Theory suggests that the nature of an affective experience (for instance, the type of discrete emotion) resulting from an event at work depends on how the event is appraised (Weiss \& Cropanzano, 1996). Cognitive appraisal theories that link thoughts with feelings similarly posit that emotions result from 
appraisals, interpretations and evaluations of situations. Such appraisals correspond to the meanings that individuals attribute to their contexts (Frijda et al., 1989; Grandey, 2008; Lazarus, 1982, 1991b; Lerner \& Keltner, 2001; Maner \& Gerend, 2007; Ortony et al., 1990; Roseman \& Smith, 2001; Smith \& Ellsworth, 1985). While there is no consensus amongst appraisal theorists on the specific patterns of emotional appraisals, they generally agree that different patterns of appraisals yield different discrete emotions (Gaddis et al., 2004; Lerner \& Keltner, 2000; Roseman, Spindel, \& Jose, 1990; Smith \& Ellsworth, 1985; Weiss, Suckow, \& Cropanzano, 1999b). Fear appraisals are generally associated with unpleasantness, uncertainty and low situational control (Lerner \& Keltner, 2000; Smith \& Ellsworth, 1985).

Most cognitive appraisal theories of emotion are based on a two-stage process in the evaluation and interpretation of situations: primary and secondary appraisal dimensions (Frijda, 1986; Frijda et al., 1989; Lazarus, 1991a; Scherer, 1988). Building on the application of cognitive appraisals of fear to employee silence at work by Kish-Gephart et al. (2009), fear can arise when managers appraise situations (a) as counter to their goals or well-being (primary appraisals) and (b) as likely to have uncertain outcomes that they are unable to control or cope with (secondary appraisals). With respect to the leadership knowing-doing gap, such appraisals of work events may shape managers' experiences of fear, which may subsequently influence the translation of their leadership knowledge into leadership action. Thus, Affective Events Theory and the underlying cognitive appraisals point to the interplay between individuals and their situational contexts in triggering feelings of fear. Building on fear appraisal tendencies, we propose that managers may experience fear when they appraise work events or situations as threatening to their goals and not under their control. Hence, it is possible that two managers who interpret the same 
work event differently, or that one manager who has different appraisals of the same situation at different times, will experience different emotions. A work event will trigger fear to the extent that a manager appraises it as fearful.

Proposition 2: Fear experiences develop through the interplay between individual leaders and their situational contexts. Leader fear occurs when leaders appraise work events or situations as fearful.

\section{Responses to Leader Fear}

Fear can be described in terms of three components: (a) the subjective experience of apprehension; (b) associated psychophysiological changes (like perspiring and increased heart rate); and (c) attempts to avoid or escape from fearful situations (Rachman, 1990: 3). The three components do not necessarily correspond. For instance, an individual might experience subjective apprehension but not show signs of psychophysiological changes despite being fearful inside. The third component of fear, namely the attempts to avoid or escape fearful situations, is worth highlighting in relation to fear and the knowing-doing gap of leaders.

A threatening situation that is controllable reduces the probability of fear due to people's preference for predictability and controllability (Grandey, 2008; Rachman, 1990). This argument is consistent with secondary cognitive appraisals, as well as evidence showing that fearful people make pessimistic judgments and risk-averse choices in the absence of certainty and control (Lerner \& Keltner, 2000, 2001; Maner \& Gerend, 2007). On the other hand, a prediction of zero or low probability of fear can result in approach behavior (Rachman, 1990). Thus, the higher the probability of fear to occur as predicted by a manager, the more likely they are to resort to 
avoidance behavior to prevent the fear, which is in line with the literature linking fear with flight and freeze responses. The key difference between the two withdrawal or protection behaviors is that whereas flight reflects escaping or separating oneself from threatening events, freeze manifests itself as the immobility in the face of fear, not necessarily escaping it, rather being paralyzed and doing nothing about it (Frijda, 1986; Grandey, 2008). Thus, avoidance behavior may take the form of an active flight defense or a passive freeze defense in situations of fear (Ohman \& Wiens, 2003), the latter falling under the term dysfunctional emotional behavior that disrupts rather than interrupts an individual's functioning and performance in the workplace (Ostell, 1996). On the other hand, both forms of avoidance have been found to reflect a phase of inertia in workplace decision-making, as feelings of apprehension about tackling an issue can take decision makers and others out of their comfort or safety zone, creating a danger zone whereby they fear becoming involved and taking action, resulting in the issue being avoided (Laundre \& Richmond, 2001; Maitlis \& Ozcelik, 2004).

In terms of leadership engagement, drawing on leader response strategies to intense criticisms by Eubanks, Antes, Friedrich, Caughron, Blackwell, Bedell-Avers, and Mumford (2010), avoidance behavior of managers may revolve around: (a) the failure to recognize the situation requiring leadership action; (b) identifying the situation but not addressing it; or (c) resisting a response by escaping the situation. In our explanation of the leadership knowing-doing gap, we propose that the gap occurs or widens in situations (b) or (c) whereby a manager recognizes the situation requiring leadership action and possesses the leadership knowledge to engage in leadership behavior, but does not fully translate this knowledge into real leadership action by freezing or flying respectively. Building on fear appraisal tendencies (Proposition 1) 
and drawing on this description of fear action tendencies, leaders may be less likely to turn their leadership knowledge into leadership action when they predict high probabilities of fear in particular situations. Hence, we propose that in experiences of fear (as triggered by the appraisals of individual leaders of their situational contexts), fearful leaders are likely to avoid or withdraw from leadership enactment. While avoidance behavior may be triggered by other factors, fear appears to be a central factor causing avoidance (Rachman, 1990). Thus, we propose that avoidance behavior resulting from leader fear can be a possible explanation behind creating or widening the knowing-doing gap of leaders.

Proposition 3: Leaders may avoid or withdraw from leadership enactment when they experience fear as triggered when they appraise work events or situations as fearful. Avoidance behavior in experiences of fear decreases the likelihood of leaders translating their leadership knowledge into leadership action and thereby contributes towards creating or widening their knowingdoing gap.

Cognitive appraisals and high predictions of fear may not necessarily result in avoidance behavior. For instance, cognitive counter-phobic coping mechanisms studied in the field of stress and coping have been found to enable individuals to resist avoidance or escape temptations (Lazarus \& Folkman, 1984). Coping can be problemfocused or emotion-focused, the former aiming to solve a problem in a particular situation, and the latter focused on decreasing the experience of a negative emotion (Gross, 1998). Thus, we suggest that coping may be one way through which managers may overcome avoidance behavior in situations that they appraise as fearful. 
In addition to flight and freeze action tendencies in fearful situations, fear may also induce behavior and motivate people to fight and approach behavior (Jacobson, 2012; Ohman \& Wiens, 2003). While flight and freeze are avoidance-focused defense mechanisms promoting the avoidance of threat, approach-focused motives can drive people towards desired opportunities (Maner \& Gerend, 2007). For example, managers may be able to act courageously in the face of fear, actively fighting their fear rather than resorting to defense and coping mechanisms (Rachman, 1990). On the other hand, managers may be able to turn the negative emotion of fear experienced in their contexts into positive energy, using fear as a motivation towards action (Gooty et al., 2010; Rachman, 1990). Thus, we suggest that managers may not only cope with their subjective experiences of fear, but may also simultaneously develop the courage to overcome it or use it in pursuit of their goals. Despite the fascination with courage in the practitioner leadership literature, there is limited work on the nature and meaning of courage with relevance to scholarly leadership research (Rate \& Sternberg, 2007; Terry, 1993). Examples of shortfalls in leader courage include avoiding a challenging action or neglecting responsibility (Katzenbach, 1996). These are consistent with our description of avoidance behavior that widens the leadership knowing-doing gap.

An alternative avenue to understanding the bridging of the leadership knowing-doing gap in the face of fear is emotion regulation. Research on emotion regulation finds that individuals may be able to consciously or unconsciously influence which emotions they experience, in which situations and at which points in time, as well as how they express and manage them (Bargh \& Williams, 2007; Gross, 1998). Emotion regulation strategies include tailoring a situation to change its emotional influence, selecting the elements of a situation to focus on, and modifying 
the cognitive meanings attached to it, which in turn shapes the response tendencies to the emotion (Gross, 1998). While more research on the predictors and outcomes of emotion regulation of leaders is needed (Gooty et al., 2010), we suggest emotion regulation processes may enable managers to approach behavior in the face of fear. Thus, although fear is traditionally viewed as avoidance-focused, it may also elicit mechanisms of approach behavior. In experiences of fear, managers may be able to resist avoidance or withdrawal, and instead approach behavior and translate their leadership knowledge into leadership action, thereby preventing or closing their leadership knowing-doing gap.

Proposition 4: Leaders may approach leadership enactment when they experience fear as triggered when they appraise work events or situations as fearful. Approach behavior in experiences of fear increases the likelihood of leaders translating their leadership knowledge into leadership action and thereby contributes towards preventing or bridging their knowing-doing gap.

\section{IMPACT OF LEADER FEAR AND THE KNOWING-DOING GAP OF LEADERSHIP}

We have thus far explored how avoidance or withdrawal behavior (for example, flight or freeze) resulting from leader fear can be an explanation behind the creation or widening of the knowing-doing gap of leaders on the one hand, and approach behavior in the face of fear (for example, fight or emotion regulation) can influence the prevention or closing of the knowing-doing gap of leaders, on the other hand. We further explore the impact of fear and the leadership knowing-doing gap on 
leadership and performance, given that leadership development and leadership effectiveness are key to achieving organizational objectives (Avolio et al., 2010; Yukl, 2010). In light of our discussion of Affective Events Theory, we highlighted the impact of affective events and affective states on work outcomes. Work events can shape the emotional states of employees, which in turn mediate the effect of work events on organizational outcomes (Weiss \& Cropanzano, 1996). Evidence from the workplace affect literature shows the impacts of affective states (moods and emotions) on performance-relevant outcomes like productivity (Wright et al., 1993; Wright \& Cropanzano, 1998), job satisfaction (Fisher, 2000; Weiss et al., 1999a), voluntary turnover (Wright \& Cropanzano, 1998), as well as risk taking, helping behavior and creativity (Brief \& Weiss, 2002). As for the leadership and affect domain, literature points to the influence of affective states on leaders, followers and performance, as previously described (Dasborough, 2006; Gaddis et al., 2004; Menges et al., 2011; Walter \& Bruch, 2009). From this, we suggest that experiences of leader fear (as triggered when managers appraise work events or situations as fearful) may influence leadership and organizational outcomes.

Emotional reactions may influence interpersonal behavior and collective performance as much as individual performance (Ostell, 1996). For instance, research in the leadership arena shows that emotions such as frustration and optimism mediate the relationship between transformational leadership and subordinate performance (McColl-Kennedy \& Anderson, 2002). Due to the multi-level nature of both leadership and emotions (Gooty et al., 2010; Gooty et al., 2009; Yammarino \& Dansereau, 2008; Yammarino et al., 2005) and taking into account the interplay between leaders, followers, dyads, collectives and contexts in the leadership phenomenon (Avolio \& Gardner, 2005; Hernandez et al., 2011; Yukl, 2010), we 
propose that leader fear and its contribution towards widening and bridging of the leadership knowing-doing gap not only influences individual leaders, but has the potential to impact on the overall leadership effectiveness in organizations.

For instance, in terms of avoidance-oriented outcomes of leader fear, managers are less likely to fully translate their leadership knowing into leadership doing, which creates or widens their leadership knowing-doing gap in turn (Proposition 2). Thereby, managers may not necessarily achieve their full leadership potential. Additionally, the knowing-doing gap of leaders caused by fear may also have an impact on followers. Due to the contagious nature of emotions, people can become infected by the emotions of others (Hatfield, Cacioppo, \& Rapson, 1994). Thus, leaders can be both receivers and senders of contagious emotions (Barsade, 2002; Rajah et al., 2011). Emotional contagion could mean that fear transported to and from leaders, followers, peers and other members across various levels of the organization may disrupt work processes, draining the energy and depleting the potential of leaders, followers and organizations.

Proposition 5: Widening the knowing-doing gap of leaders can have negative impacts on leadership effectiveness and organizational effectiveness.

On the other hand, with respect to approach-oriented outcomes of leader fear, managers are more likely to transfer their leadership knowledge into leadership action, which closes or even prevents the leadership knowing-doing gap (Proposition 3). Thus, managers may more fully apply what they know about leadership into real leadership action, and thereby may be closer to realizing their leadership potential. Moreover, bridging the knowing-doing gap may result in knowledge transfer beyond 
the individual leader. Drawing on the notion that context plays a role in creating knowledge and organizational learning (Argote \& Miron-Spektor, 2011), the interplay between managers and their situational contexts not only provides the mechanism for managers in translating their leadership learning into their own leadership action, but also in transferring their leadership knowledge to followers, peers and other members of their organizations. Additionally, leaders may play a role in creating learning cultures that promote participation, openness and psychological safety, thus supporting learning across all levels of the organization (Berson, Nemanich, Waldman, Galvin, \& Keller, 2006). Empirical evidence shows that leadership development can transform organizations (Day, 2011) through positively influencing participants' attitudes, behaviors and performance (Avolio, Walumbwa, \& Weber, 2009; Collins \& Holton, 2004). Research finds a range from a low negative to above $200 \%$ return on human development investment (RODI) to organizations from different leadership development interventions, and indicates that leadership development can result in significant positive returns to organizations in terms of leadership effectiveness (Avolio et al., 2010). Correspondingly, closing the knowingdoing gap can potentially contribute towards overcoming the transfer problem at the individual and contextual level, and may have positive impacts through enhancing leadership development and leadership effectiveness across various levels of organizations.

Proposition 6: Bridging the knowing-doing gap of leaders can have positive impacts on leadership effectiveness and organizational effectiveness. 
In this paper, we use Affective Events Theory as our underlying theoretical lens to develop an initial framework on the role of leader fear in the knowing-doing gap of leadership. Integrating arguments from the cognitive, affective, and behavioral domains, and focusing on individual and contextual loci of leadership, we develop a framework in which managers' experiences of workplace fear are triggered by their appraisals of their situational contexts, which in turn influence the translation of their leadership knowledge into leadership action, ultimately impacting on leadership effectiveness and organizational effectiveness. Our multidimensional theoretical framework, as shown in Figure 1, can form a starting point for further theory building and future empirical research on the knowing-doing of leadership, a challenge that is compelling in practice yet novel in research. The following section expands on how our framework adds to the existing literature primarily in the areas of leadership development as well as emotions and leadership.

\section{Theoretical Contributions}

First, with respect to leadership development, our framework is one of the first attempts to introduce and uncover the leadership knowing-doing gap. It complements existing approaches that challenge the view that holding a formal leadership position in an organization inherently conveys leadership (DeRue \& Ashford, 2010). By exploring the knowing-doing gap of leadership, we highlight the perspective that attending leadership development programs and accumulating other forms of leadership knowledge over time does not necessarily prescribe leadership engagement (Blanchard et al., 2007; Pfeffer \& Sutton, 1999). Although leadership development remains one of the least explored areas within leadership theory and research (Avolio 
et al., 2010; Avolio, 2007; Day, Harrison, \& Halpin, 2008), the rising interest in the field is reflected in the sheer volume of recent literature on the topic. However, the work that does exist around the knowing-doing gap of leadership is dominated by publications for practice audiences (De Vita, 2009; Jensen, 2011; Raynor, 2010; Weber, 2011; Zenger, Folkman, \& Edinger, 2011), which are largely based on anecdotic evidence. It is hence not clear how the knowing-doing gap of leaders can be conceptually described and identified. Responding to a call to explore individual and contextual influences on the transfer of leadership learning into practice (Avolio et al., 2010), we provide an initial conceptualization of the leadership knowing-doing gap and introduce an affect-based perspective on possible explanations behind the widening and bridging of the leadership knowing-doing gap. Our proposed theoretical framework highlights how the emotion of fear (as triggered by managers' appraisals of their situational contexts) may have an impact on the translation of leadership knowledge into leadership practice, either by disrupting it and therefore creating or widening the knowing-doing gap of leadership on the one hand, or contributing towards bridging such gap on the other hand. Our theory also responds to a suggestion in the training literature to explore why trainees may make a choice not to transfer an open skill into actual practice (Blume et al., 2010). It is argued that in the development of an open or interpersonal skill (such as leadership), trainees may have more freedom in terms of whether, how and when to transfer the learned skill to the job, as opposed to a closed or technical skill (Blume et al., 2010). Thus, our initial framework on the leadership knowing-doing gap serves as an example of knowledge of an open skill not being transferred into real action.

Second, in contributing towards existing approaches to emotions and leadership, we add to theory building in the area of negative discrete emotions. The 
disproportionate emphasis on moods over discrete emotions (Brief \& Weiss, 2002; Gooty et al., 2009), and positive emotions over negative emotions in the extant literature (Gooty et al., 2010) provides the backdrop to our work. Moreover, fear attracts less attention in the organizational literature in contrast to other emotions like anger, envy, and happiness (Kish-Gephart et al., 2009) and the literature that links leadership with the emotion of fear in particular is scarce. Our paper is one of few scholarly explorations of fear in leaders as opposed to fear of leaders within the leadership arena. It contributes specifically by looking at fear in leaders and how it may influence leadership engagement and leadership effectiveness in organizations. Further, while emotions are dynamic and context-specific, varying for each person over time, they are more often than not treated as stable or static constructs in the organizational literature (Beal, Weiss, Barros, \& MacDermid, 2005; Gooty et al., 2009). Our framework on fear and the leadership knowing-doing gap sheds light on within- and between-person variability of the phenomena, taking into account the role of the context in which fear occurs. We highlight the interplay between individuals and their situational context. We also contribute to the understanding of fear at the intra-individual level, describing how fear may arise by managers' appraisals of their different work contexts. A manager may appraise similar work events differently at different points in time, and two managers may appraise the same work event differently, for instance. We describe how fear responses and leadership behaviors might differ over time, impacting on the translation of leadership learning into leadership doing in different ways, avoiding or approaching leadership doing. Thus, we point to the significance of exploring fear in leaders, and advance the understanding of fear beyond its prevailing avoidance action tendencies. 
Third, our framework draws on and integrates arguments from a number of relevant streams of literature to enhance our understanding of both emotions and leadership. An experience of emotion can consist of several elements, including physiological, psychological, motivational, cognitive and behavioral elements (Gooty et al., 2009). Similarly, leadership involves perceptions, attitudes, emotions and behaviors amongst other elements (Hernandez et al., 2011). For this paper, Affective Events Theory (Weiss \& Cropanzano, 1996) is our predominant lens through which the leadership knowing-doing gap is explored, and we chose to rely on cognitive and behavioral theories and processes, which are more applicable to organizational research (Gooty et al., 2009) and are more relevant to our theoretical lens in our inquiry on the leadership knowing-doing gap. Specifically, we draw on cognitive appraisal theories (Frijda, 1986; Frijda et al., 1989; Lazarus, 1982; Lazarus, 1991a; Lazarus, 1991b; Lerner \& Keltner, 2000, 2001; Maner \& Gerend, 2007; Ortony et al., 1990; Roseman \& Smith, 2001; Roseman et al., 1990; Scherer, 1988; Smith \& Ellsworth, 1985; Weiss et al., 1999b) to describe how leaders may interpret their situational contexts as fearful. Additionally, we use avoidance and approach behavior responses to fear (Frijda, 1986; Frijda et al., 1989; Grandey, 2008; Ohman \& Wiens, 2003; Rachman, 1990) to explain the role of leader fear in influencing the widening and bridging of the leadership knowing doing gap respectively. Further, we draw on contextual theories of leadership (Antonakis et al., 2003; Osborn et al., 2002; Porter \& McLaughlin, 2006; Shamir \& Howell, 1999) to highlight the impact of the context in which leadership is embedded on the appraisals, responses and impacts of fear and the leadership knowing-doing gap. By doing so, our multidimensional theoretical framework illustrates the linkages between these theories, providing an understanding of the leadership knowing-doing gap that takes into account the contextual influences 
on the cognition, emotion, and behavior of individual leaders. Thus, our framework contributes towards leadership and emotions from multiple theoretical domains and perspectives to capture a more inclusive picture of the leadership knowing-doing gap.

Our proposed theoretical framework aims to build a foundation for the development of new leadership theory with particular relevance to the literature streams of leadership development as well as emotions and leadership. We make recommendations in the following section on new directions for extending our work, as well as future research suggestions aimed at generating advanced insights into the issues raised in this paper.

\section{Limitations and Future Research Directions}

In our theoretical exploration of the widening and bridging knowing-doing gap of leadership we focus on knowing that precedes doing, following the premise that it is difficult to understand how individuals could know and not do in contexts where knowledge is a product of actual doing on the job (Pfeffer \& Sutton, 2000). Thus, we look at the transfer of knowing into doing. Contexts in which doing results in knowing, as well as learning processes and other possible antecedents to knowing are excluded from the scope of this paper. We highlight the influence of context on the knowing-doing gap of leadership. Our proposed theoretical framework can form an initial foundation for understanding the topic, and can be extended by exploring whether the knowing-doing gap can occur in contexts where knowing and doing are intertwined, such as knowing through practice (Nicolini, 2011), action learning (Pedler, 2008), experiential learning (Hoover et al., 2010), and reflection (De DÉA Roglio \& Light, 2009). 
Further, there is no general model for the complex topic of leadership development (Avolio, 2007; Avolio et al., 2009; Day, 2000; Day et al., 2014), nor well-established constructs and measures that are suitable for a deductive research strategy with relevance to the leadership knowing-doing gap. We provide a starting point into conceptually describing the knowing-doing gap of leadership. Our suggestion for further in-depth theory building is to pursue qualitative research designs to explore the interpretation of the knowing-doing gap from the perspective of leaders, and potentially followers, in order to understand how they make sense of the knowing-doing gap within their leadership contexts. It would be useful to find for instance how managers describe and interpret the differences in their own experiences of tapping, to varying degrees, into their leadership learning in translating their leadership knowledge into leadership action in different situations.

We explore the role of leader fear as a possible explanation behind the widening and bridging of the leadership knowing-doing gap, taking into account the interplay of individual managers and their situational contexts. Due to the scarcity of research on fear in leaders, we also call for inductive research to illuminate how managers perceive and manage the impact of fear on the translation of their leadership knowledge into action within their leadership contexts. We propose that events can be particularly fearful depending on individual appraisals of them. Our theory opens up avenues to explore the context in which leadership is embedded, which is more often than not neglected or treated as a secondary afterthought in the leadership literature (Antonakis et al., 2003; Osborn et al., 2002; Porter \& McLaughlin, 2006; Shamir \& Howell, 1999). We encourage exploring the kinds of events that managers may appraise as fearful and how they respond to these. It would be useful to explore what is it about events, specifically, that triggers avoidance behavior and thus disrupts 
leadership, and what characteristics would promote approach behavior. This would provide a greater understanding of the circumstances under which leaders would translate, to varying degrees, their leadership knowledge into leadership practice. It would heed the calls for exploring how individual differences between leaders may shape the variations in their responses to similar events and contexts (Gooty et al., 2010; Morgeson \& DeRue, 2006) and also respond to the calls for more attention to the organizational context as a key factor influencing leadership behavior and effectiveness (Porter \& McLaughlin, 2006). It would further contribute towards calls for more work on the organizational climates that can be related to the experience of fear (Brief \& Weiss, 2002), as well as the impact of negative leader emotions, and how these may generalize to organizations (Gooty et al., 2010).

Finally, while we propose the approach-focused fight response to fear as a possible explanation behind preventing or closing the knowing-doing gap of leadership, further exploration of leader courage in the face of fear, or in its own right in the absence of fear, could be a promising path towards overcoming the knowingdoing gap of leadership. There is a general lack of clarity on the definition of courage (see Peterson and Seligman (2004) for disparate definitions), and limited work on the nature and meaning of courage with relevance for scholarly leadership research (Rate \& Sternberg, 2007; Terry, 1993) which raises a challenge to rely on it in conceptualizing the leadership knowing-doing gap. We propose that courage may elicit a mechanism of approach behavior, and future research could expand on this argument by exploring how courage can be conceptualized within the leadership domain, and the role it may play in leadership enactment and leadership effectiveness. This would enrich our understanding of what it takes to develop and promote the courage to fully translate leadership knowing into leadership doing. 


\section{CONCLUSION}

In this paper we focus on the leader and context loci of leadership and draw on emotional, cognitive, and behavioral mechanisms to explore why managers who know what leadership entails and how to engage in leadership do not necessarily translate their leadership knowledge into leadership action. We present leader fear as a possible explanation behind the leadership knowing-doing gap, showing how experiences of fear can either disrupt the transfer of leadership knowledge into leadership practice and therefore create or widen the leadership knowing-doing gap on the one hand, or contribute towards preventing or bridging the gap on the other hand. We highlight how fear and the leadership knowing-doing gap can be influenced by, and potentially influence, individual managers and their leadership contexts. Our initial framework provides a starting point for understanding fear and the leadership knowing-doing gap, and our hope is to spur interest for future research on the topic. 


\section{REFERENCES}

Anderson, C. J. (2003). The psychology of doing nothing: Forms of decision avoidance result from reason and emotion. Psychological Bulletin, 129(1), 139-167.

Antonakis, J., Avolio, B. J., \& Sivasubramaniam, N. (2003). Context and leadership: An examination of the nine-factor full-range leadership theory using the Multifactor Leadership Questionnaire. The Leadership Quarterly, 14(3), 261295.

Argote, L., \& Miron-Spektor, E. (2011). Organizational learning: From experience to knowledge. Organization Science, 22(5), 1123-1137.

Ashkanasy, N. M., Zerbe, W. J., \& Härtel, C. E. J. (2002). Managing emotions in the workplace. New York: Sharpe.

Ashkanasy, N. M., Zerbe, W. J., \& Härtel, C. E. J. (2005). Research on emotion in organizations: The effect of affect in organizational settings (Vol. 1). Bingley: Emerald.

Avolio, Avey, J. B., \& Quisenberry, D. (2010). Estimating return on leadership development investment. The Leadership Quarterly, 21(4), 633-644.

Avolio, B. J. (2007). Promoting more integrative strategies for leadership theorybuilding. American Psychologist Special Issue: Leadership, 62(1), 25-33.

Avolio, B. J., \& Gardner, W. L. (2005). Authentic leadership development: Getting to the root of positive forms of leadership. The Leadership Quarterly, 16(3), 315338.

Avolio, B. J., Walumbwa, F. O., \& Weber, T. J. (2009). Leadership: Current theories, research, and future directions. Annual Review of Psychology, 60, 421-449.

Baldwin, T. T., \& Ford, J. K. (1988). Transfer of training: A review and directions for future research. Personnel Psychology, 41(1), 63-105.

Baldwin, T. T., Pierce, J. R., Joines, R. C., \& Farouk, S. (2011). The elusiveness of applied management knowledge: A critical challenge for management educators. Academy of Management Learning \& Education, 10(4), 583-605.

Bargh, J. A., \& Williams, L. E. (2007). The nonconscious regulation of emotion. In J. J. Gross (Ed.), Handbook of Emotion Regulation (pp. 429-446). New York: Guilford Publication.

Barsade, S. G. (2002). The ripple effect: emotional contagion and its influence on group behavior. Administrative Science Quarterly, 47(4), 644-675.

Barsade, S. G., \& Gibson, D. E. (2007). Why Does Affect Matter in Organizations? Academy of Management Perspectives, 21(1), 36-59.

Beal, D. J., Weiss, H. M., Barros, E., \& MacDermid, S. M. (2005). An Episodic Process Model of Affective Influences on Performance. Journal of Applied Psychology, 90(6), 1054-1068.

Bennis, W. G., \& O'Toole, J. (2005). How business schools lost their way. Harvard Business Review, 83(5), 96-104.

Berson, Y., Nemanich, L. A., Waldman, D. A., Galvin, B. M., \& Keller, R. T. (2006). Leadership and organizational learning: A multiple levels perspective. The Leadership Quarterly, 17(6), 577-594.

Blanchard, K., Meyer, P. J., \& Ruhe, D. (2007). Know can do: Put your know-how into action. San Fransisco: Berrett-Koehler Publishers. 
Blume, B. D., Ford, J. K., Baldwin, T. T., \& Huang, J. L. (2010). Transfer of training: A meta-analytic review. Journal of Management, 36(4), 1065-1105.

Brief, A. P., \& Weiss, H. M. (2002). Organizational behavior: Affect in the workplace. Annual Review of Psychology, 53(1), 279-307.

Carter, L. (2009). Warrior ethos. Leadership Excellence, 26(7), 13-14.

Chan, K. Y., \& Drasgow, F. (2001). Toward a theory of individual differences and leadership: Understanding the motivation to lead. Journal of Applied Psychology, 86(3), 481-498.

Collins, D. B., \& Holton, E. F. (2004). The effectiveness of managerial leadership development programs: A meta-analysis of studies from 1982 to 2001. Human Resource Development Quarterly, 15(2), 217-248.

Colonna, J. (2006). The fear factor for supply chain managers offers risk and reward. Healthcare Purchasing News, 30(5), 64-65.

Dansereau, F., Seitz, S. R., Chiu, C.-Y., Shaughnessy, B., \& Yammarino, F. J. (2013). What makes leadership, leadership? Using self-expansion theory to integrate traditional and contemporary approaches. The Leadership Quarterly, 24(6), 798-821.

Dasborough, M. T. (2006). Cognitive asymmetry in employee emotional reactions to leadership behaviors. The Leadership Quarterly, 17(2), 163-178.

Day, D. V. (2000). Leadership development: A review in context. The Leadership Quarterly, 11(4), 581-613.

Day, D. V. (2011). Leadership Development. In A. Bryman, D. Collinson, K. Grint, B. Jackson, \& M. Uhl-Bien (Eds.), The Sage handbook of leadership (pp. 3751). London: Sage Publications Ltd.

Day, D. V., Fleenor, J. W., Atwater, L. E., Sturm, R. E., \& McKee, R. A. (2014). Advances in leader and leadership development: A review of 25 years of research and theory. The Leadership Quarterly, 25(1), 63-82.

Day, D. V., Harrison, M. M., \& Halpin, S. M. (2008). An integrative approach to leader development: connecting adult development, identity, and expertise. New York: Routledge.

De DÉA Roglio, K., \& Light, G. (2009). Executive MBA programs: the development of the reflective executive. Academy of Management Learning \& Education, $8(2), 156-173$.

de Jong, T., \& Ferguson-Hessler, M. G. M. (1996). Types and qualities of knowledge. Educational Psychologist, 31(2), 105-113.

De Vita, E. (2009). The knowing-doing gap. Third Sector, 21.

DeRue, D. S., \& Ashford, S. J. (2010). Who will lead and who will follow? A social process of leadership identity construction in organizations. Academy of Management Review, 35(4), 627-647.

Eubanks, D. L., Antes, A. L., Friedrich, T. L., Caughron, J. J., Blackwell, L. V., Bedell-Avers, K. E., \& Mumford, M. D. (2010). Criticism and outstanding leadership: An evaluation of leader reactions and critical outcomes. The Leadership Quarterly, 21(3), 365-388.

Fineman, S. (2003). Understanding Emotion at Work. London: Sage Publications.

Fisher, C. D. (2000). Mood and emotions while working: Missing pieces of job satisfaction? Journal of Organizational Behavior, 21(2), 185-202.

Fisher, C. D., \& Ashkanasy, N. M. (2000). The emerging role of emotions in work life: An introduction. Journal of Organizational Behavior, 21(2), 123-129.

Forgas, J. P. (1995). Mood and Judgment: The Affect Infusion Model (AIM). Psychological Bulletin, 117(1), 39-66. 
Frijda, N. H. (1986). The Emotions. Cambridge: Cambridge University Press.

Frijda, N. H., Kuipers, P., \& ter Schure, E. (1989). Relations among emotion, appraisal, and emotional action readiness. Journal of Personality \& Social Psychology, 57(2), 212-228.

Fry, L. W. (2003). Toward a theory of spiritual leadership. The Leadership Quarterly, 14(6), 693-727.

Gaddis, B., Connelly, S., \& Mumford, M. D. (2004). Failure feedback as an affective event: Influences of leader affect on subordinate attitudes and performance. The Leadership Quarterly, 15(5), 663-686.

Gardner, W. L., Lowe, K. B., Moss, T. W., Mahoney, K. T., \& Cogliser, C. C. (2010). Scholarly leadership of the study of leadership: A review of The Leadership Quarterly's second decade, 2000-2009. The Leadership Quarterly, 21(6), 922958.

Gersick, C. J. G., \& Hackman, J. R. (1990). Habitual routines in task-performing groups. Organizational Behavior and Human Decision Processes, 47(1), 6597.

Gooty, J., Connelly, S., Griffith, J., \& Gupta, A. (2010). Leadership, affect and emotions: A state of the science review. The Leadership Quarterly, 21(6), 979-1004.

Gooty, J., Gavin, M., \& Ashkanasy, N. M. (2009). Emotions research in OB: The challenges that lie ahead. Journal of Organizational Behavior, 30(6), 833-838.

Grandey, A. A. (2008). Emotions at Work: A Review and Research Agenda. In J. Barling \& C. L. Cooper (Eds.), The Sage Handbook of Organizational Behavior - Volume One: Micro Approaches (pp. 234-261). London: Sage Publications.

Gross, J. J. (1998). The Emerging Field of Emotion Regulation: An Integrative Review. Review of General Psychology, 2(3), 271-299.

Hannah, S. T., \& Avolio, B. J. (2010). Ready or not: How do we accelerate the developmental readiness of leaders? Journal of Organizational Behavior, 31(8), 1181-1187.

Hatfield, E., Cacioppo, J. T., \& Rapson, R. L. (1994). Emotional Contagion. Cambridge: Cambridge University Press.

Hedlund, J., Forsythe, G. B., Horvath, J. A., Williams, W. M., Snook, S., \& Sternberg, R. J. (2003). Identifying and assessing tacit knowledge: understanding the practical intelligence of military leaders. The Leadership Quarterly, 14(2), 117-140.

Hernandez, M., Eberly, M. B., Avolio, B. J., \& Johnson, M. D. (2011). The loci and mechanisms of leadership: Exploring a more comprehensive view of leadership theory. The Leadership Quarterly, 22(6), 1165-1185.

Hoover, J. D., Giambatista, R. C., Sorenson, R. L., \& Bommer, W. H. (2010). Assessing the effectiveness of whole person learning pedagogy in skill acquisition. Academy of Management Learning \& Education, 9(2), 192-203.

Huy, Q. N. (2012). Emotions in strategic organization: Opportunities for impactful research. Strategic Organization, 10(3), 240-247.

Izard, C. E. (1993). Four systems for emotion activation: cognitive and noncognitive processes. Psychological Review, 100(1), 68-90.

Jacobson, L. (2012). Using fear to your advantage in leadership. Canadian Manager, $37(3), 20-21$.

Jensen, M. L. (2011). Nurturing self-knowledge: the impact of a leadership development program. OD Practitioner, 43(3), 30-35. 
Kark, R. (2011). Games managers play: Play as a form of leadership development. Academy of Management Learning \& Education, 10(3), 507-527.

Katzenbach, J. R. (1996). Real change leaders: How you can create growth and high performance at your company. London: Nicholas Brealey.

Kish-Gephart, J. J., Detert, J. R., Treviño, L. K., \& Edmondson, A. C. (2009). Silenced by fear: The nature, sources, and consequences of fear at work. Research in Organizational Behavior, 29(0), 163-193.

Laundre, G. L., \& Richmond, L. E. (2001). How to Expand Your Comfort Zone: Release the Fear That Holds You Back. Michigan: Richmond House.

Lazarus, R. S. (1982). Thoughts on the relations between emotion and cognition. American Psychologist, 37(9), 1019-1024.

Lazarus, R. S. (1991a). Emotion and Adaptation. Oxford: Oxford University Press.

Lazarus, R. S. (1991b). Progress on a cognitive-motivational-relational theory of emotion. American Psychologist, 46(8), 819-834.

Lazarus, R. S., \& Folkman, S. (1984). Stress, Appraisal, and Coping. New York: Springer Publishing Company.

Lee, T. W., \& Mitchell, T. R. (1994). An Alternative Approach: The Unfolding Model of Voluntary Employee Turnover. Academy of Management Review, 19(1), 51-89.

Lerner, J. S., \& Keltner, D. (2000). Beyond valence: Toward a model of emotionspecific influences on judgement and choice. Cognition \& Emotion, 14(4), 473-493.

Lerner, J. S., \& Keltner, D. (2001). Fear, anger, and risk. Journal of Personality \& Social Psychology, 81(1), 146-159.

Louis, M. R. (1980). Surprise and Sense Making: What Newcomers Experience in Entering Unfamiliar Organizational Settings. Administrative Science Quarterly, 25(2), 226-251.

Maitlis, S., \& Ozcelik, H. (2004). Toxic Decision Processes: A Study of Emotion and Organizational Decision Making. Organization Science, 15(4), 375-393.

Maner, J. K., \& Gerend, M. A. (2007). Motivationally selective risk judgments: Do fear and curiosity boost the boons or the banes? Organizational Behavior and Human Decision Processes, 103(2), 256-267.

McCall, M. W. (2004). Leadership development through experience. Academy of Management Executive, 18(3), 127-130.

McColl-Kennedy, J. R., \& Anderson, R. D. (2002). Impact of leadership style and emotions on subordinate performance. The Leadership Quarterly, 13(5), 545559.

Menges, J. I., Walter, F., Vogel, B., \& Bruch, H. (2011). Transformational leadership climate: Performance linkages, mechanisms, and boundary conditions at the organizational level. The Leadership Quarterly, 22(5), 893-909.

Merriam-Webster Dictionary. (2012). Fear. Retrieved from http://www.merriamwebster.com/dictionary/fear

Monson, T. C., Hesley, J. W., \& Chernick, L. (1982). Specifying when personality traits can and cannot predict behavior: An alternative to abandoning the attempt to predict single-act criteria. Journal of Personality \& Social Psychology, 43(2), 385-399.

Morgeson, F. P. (2005). The External Leadership of Self-Managing Teams: Intervening in the Context of Novel and Disruptive Events. Journal of Applied Psychology, 90(3), 497-508. 
Morgeson, F. P., \& DeRue, D. S. (2006). Event criticality, urgency, and duration: Understanding how events disrupt teams and influence team leader intervention. The Leadership Quarterly, 17(3), 271-287.

Nicolini, D. (2011). Practice as the site of knowing: Insights from the field of telemedicine. Organization Science, 22(3), 602-620.

Ohman, A., \& Wiens, S. (2003). On the automaticity of autonomic responses in emotion: An evolutionary perspective. In R. J. A. Davidson, K. R. A. Scherer, \& H. H. A. Goldsmith (Eds.), Handbook of Affective Sciences (pp. 256-275). Oxford: Oxford University Press.

Ortony, A., Clore, G. L., \& Collins, A. (1990). The Cognitive Structure of Emotions. Cambridge: Cambridge University Press.

Osborn, R. N., Hunt, J. G., \& Jauch, L. R. (2002). Toward a contextual theory of leadership. The Leadership Quarterly, 13(6), 797-837.

Ostell, A. (1996). Managing Dysfunctional Emotions in Organizations. Journal of Management Studies, 33(4), 525-557.

Pedler, M. (2008). Action learning for managers. Hampshire: Gower Publishing Ltd.

Peterson, C., \& Seligman, M. E. P. (2004). Character strengths and virtues: A handbook and classification. New York: Oxford University Press.

Pfeffer, J., \& Sutton, R. (1999). Knowing "what" to do is not enough: Turning knowledge into action. California Management Review, 42(1), 83-108.

Pfeffer, J., \& Sutton, R. (2000). The knowing-doing gap: How smart companies turn knowledge into action. Boston: Harvard Business Press.

Porter, L. W., \& McLaughlin, G. B. (2006). Leadership and the organizational context: Like the weather? The Leadership Quarterly, 17(6), 559-576.

Rachman, S. J. (1990). Fear and Courage. New York: W. H. Freeman and Company.

Rajah, R., Song, Z., \& Arvey, R. D. (2011). Emotionality and leadership: Taking stock of the past decade of research. The Leadership Quarterly, 22(6), 11071119.

Rate, C. R., \& Sternberg, R. J. (2007). When Good People Do Nothing: A Failure of Courage. In J. Langan-Fox, C. L. Cooper, \& R. J. Klimoski (Eds.), Research Companion to the Dysfunctional Workplace: Management Challenges and Symptoms (pp. 3-21). Cheltenham: Edward Elgar Publishing Ltd.

Raynor, M. E. (2010). What's wrong with what is that it's not how. Conference Board Review, 47(2), 66-67.

Rogg, K. L., Schmidt, D. B., Shull, C., \& Schmitt, N. (2001). Human resource practices, organizational climate, and customer satisfaction. Journal of Management, 27(4), 431-449.

Roseman, I. J., \& Smith, C. A. (2001). Appraisal theory: Overview, assumptions, varieties, controversies. In K. R. Scherer, A. Schorr, \& T. Johnstone (Eds.), Appraisal processes in emotion: theory, methods, research (pp. 3-19). Oxford: Oxford University Press.

Roseman, I. J., Spindel, M. S., \& Jose, P. E. (1990). Appraisals of Emotion-Eliciting Events: Testing a Theory of Discrete Emotions. Journal of Personality \& Social Psychology, 59(5), 899-915.

Rubin, R. S., \& Dierdorff, E. C. (2009). How relevant is the MBA? Assessing the alignment of required curricula and required managerial competencies. Academy of Management Learning \& Education, 8(2), 208-224.

Ryan, K., \& Oestreich, D. K. (1998). Driving fear out of the workplace: Creating the high-trust, high-performance organization (2nd ed.). San Francisco: JosseyBass. 
Scherer, K. R. (1988). Criteria for Emotion-Antecedent Appraisal: A Review. In V. Hamilton, G. H. Bower, \& N. H. Frijda (Eds.), Cognitive Perspectives on Emotion and Motivation (pp. 89-126). The Netherlands: Kluwer Academic Publishers.

Shamir, B., \& Howell, J. M. (1999). Organizational and contextual influences on the emergence and effectiveness of charismatic leadership. The Leadership Quarterly, 10(2), 257-283.

Smith, C. A., \& Ellsworth, P. C. (1985). Patterns of Cognitive Appraisal in Emotion. Journal of Personality \& Social Psychology, 48(4), 813-838.

Steel, P. (2007). The nature of procrastination: A meta-analytic and theoretical review of quintessential self-regulatory failure. Psychological Bulletin, 133(1), 65-94.

Tannenbaum, S. I. (1997). Enhancing continuous learning: Diagnostic findings from multiple companies. Human Resource Management, 36(4), 437-452.

Terry, R. W. (1993). Authentic leadership: courage in action. San Francisco: JosseyBass Publishers.

Thayer, R. E. (1989). The Biopsychology of Mood and Arousal. Oxford: Oxford University Press.

Trevino, L. K. (1992). The Social Effects of Punishment in Organizations: A Justice Perspective. Academy of Management Review, 17(4), 647-676.

Walter, F., \& Bruch, H. (2009). An Affective Events Model of Charismatic Leadership Behavior: A Review, Theoretical Integration, and Research Agenda. Journal of Management, 35(6), 1428-1452.

Weber, E. (2011). Learning is the lever for change: Making the leap to effective learning transfer. Training \& Development in Australia, 38(3), 04-05.

Weiss, H. M., \& Beal, D. J. (2005). Reflections on Affective Events Theory. In N. M. Ashkanasy, W. J. Zerbe, \& C. E. J. Härtel (Eds.), Research on Emotion in Organizations: The Effect of Affect in Organizational Settings (Vol. 1, pp. 122). Bingley: Emerald.

Weiss, H. M., \& Cropanzano, R. (1996). Affective Events Theory: A Theoretical Discussion of the Structure, Causes and Consequences of Affective Experiences at Work. Research in Organizational Behavior, 18, 1-74.

Weiss, H. M., Nicholas, J. P., \& Daus, C. S. (1999a). An examination of the joint effects of affective experiences and job beliefs on job satisfaction and variations in affective experiences over time. Organizational Behavior and Human Decision Processes, 78(1), 1-24.

Weiss, H. M., Suckow, K., \& Cropanzano, R. (1999b). Effects of Justice Conditions on Discrete Emotions. Journal of Applied Psychology, 84(5), 786-794.

Weiss, W. H. (2004). Effective leadership: What are the requisites? Supervision, 65(1), 14-17.

Wright, T. A., Bonett, D. G., \& Sweeney, D. A. (1993). Mental health and work performance: Results of a longitudinal field study. Journal of Occupational \& Organizational Psychology, 66(4), 277-284.

Wright, T. A., \& Cropanzano, R. (1998). Emotional exhaustion as a predictor of job performance and voluntary turnover. Journal of Applied Psychology, 83(3), 486-493.

Yammarino, F. J., \& Dansereau, F. (2008). Multi-level nature of and multi-level approaches to leadership. The Leadership Quarterly, 19(2), 135-141.

Yammarino, F. J., Dionne, S. D., Uk Chun, J., \& Dansereau, F. (2005). Leadership and levels of analysis: A state-of-the-science review. The Leadership Quarterly, 16(6), 879-919. 
Yukl, G. A. (2010). Leadership in organizations (7th ed.). London: Pearson.

Zenger, J. H., Folkman, J. R., \& Edinger, S. K. (2011). Making yourself indispensable. Harvard Business Review, 89(10), 84-92. 


\section{FIGURE 1}

\section{Initial Theoretical Framework}

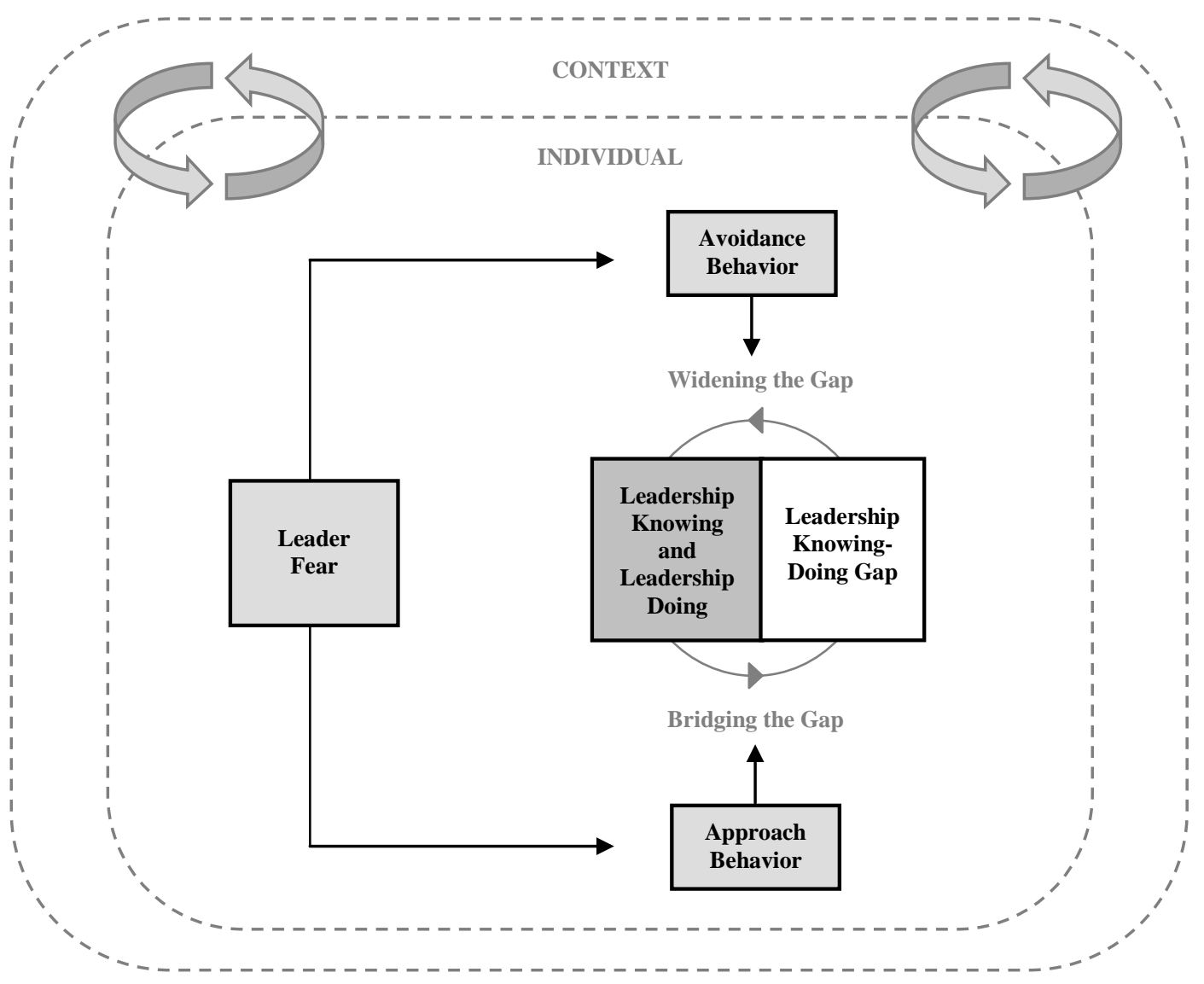

